\title{
Biodiversity of freshwater algae and cyanobacteria on deglaciated northern part of James Ross Island, Antarctica. A preliminary study.
}

\author{
Kateřina Skácelová ${ }^{1 *}$, Miloš Barták $^{l}$, Pavel Coufalík ${ }^{2}$, Daniel Nývlt ${ }^{l}$, \\ Kateřina Trnkovál \\ ${ }^{1}$ Department of Experimental Biology, Laboratory of Photosynthetic Processes, Faculty \\ of Science, Masaryk University, University Campus - Bohunice, Kamenice 5, 62500 \\ Brno, Czech Republic \\ ${ }^{2}$ Department of Chemistry, Faculty of Science, Masaryk University, University Campus \\ - Bohunice, Kamenice 5, 625 00, Brno, Czech Republic
}

\begin{abstract}
Freshwater algae and cyanobacteria have been studied at the James Ross Island (Antarctica) since the first Czech expedition to the James Ross Island area in austral summer of 2004. Main emphasis, however, has been devoted to cyanobacteria and diatoms. Therefore, recent knowledge on biodiversity of freshwater species of green algae is fragmentary. The main aim of presented study was to contribute to species list of green algae and cyanobacteria from James Ross Island. To evaluate species richness of algae and cyanobacteria, samples of water/mats from 6 different lakes, shallow ponds, and seepages located in northern deglaciated part of the James Ross Island were collected in austral summers 2012 and 2013, respectively. The samples were analysed using optical microscopy approach after transport to Czech laboratories. Algal and cyanobacterial taxa were determined according to morphological characteristics. Frequencies of individual taxa occurrence in samples were evaluated. Species richness differences between sampling sites was found. Dominating taxa differed between collection sites as well. Altogether, 41 algal and cyanobacterial taxa were found. Some species and genera: Cosmarium sp., Actinotaenium curtum, Staurastrum punctulatum and Chlorobotrys regularis are reported for James Ross Island for the first time. In some samples, there were some species that remained undetermined due to limitations of light microscopy and morphological approach. We plan to sample those locations of the James Ross Island that have never been investigated before for future studies
\end{abstract}

Key words: polar lakes, ponds, seepages, freshwater ecosystems

DOI: $10.5817 / \mathrm{CPR} 2013-2-12$

\footnotetext{
Received October 17, 2013, accepted December 11, 2013.

*Corresponding author: Kateřina Skácelová <katka.skacel@volny.cz>

Acknowledgements: The authors thank to the infrastructure of the CzechPolar for providing facilities necessary for sample collection, their storage and handling before microscopic study. Help of Gema Gonzales with microscopic analyses is acknowledged. Daniel Nývlt work of this paper has been supported by the project „Employment of Best Young Scientists for International Cooperation Empowerment" (CZ.1.07/2.3.00/30.0037) co-financed from European Social Fund and the state budget of the Czech Republic. The authors also acknowledge the help provided by Jiří Komárek (Třeboň, CZ) in determination of some cyanobacteria.
} 


\section{Introduction}

Freshwater algae and cyanobacteria are quite abundant in Maritime Antarctica, especially along the Trinity Peninsula. They occur in a wide variety of ecosystems ranging from bare rock and soils/ regolith, soil crusts and microbiological mats, moss cushions, streams, seepages, lakes and wet bottom of glaciers, snow and ice. Since the pioneering study of Cameron (1970), who reported microbes and algae from Deception Island, there have been more than 50 studies devoted to a variety of biological/ecological aspects of algae thriving in such ecotopes. From a bibliographic survey (Skácelová et Barták, MS in prep.), it follows that majority of algal and cyanobacterial samples have been collected from Western side of the Trinity Peninsula, the South Shetlands and Argentinian Islands in particular (see e.g. Zidarova 2008, Temniskova-Topalova et Kirjakov 2002). The islands east of the Trinity Peninsula have been sampled much less frequently and thus information on biodiversity of green algae (excluding diatoms - see details below) is still at the beginning. However, in spite of the fact that the first report on freshwater ecosystems of the James Ross Island (East of the Antarctic Peninsula) dates back to the early 90-ies of the last century (Hawes et Brazier 1991), numerous cyanobacterial species and their more than 70 morphotypes are reported from the James Ross Island (Komárek et Elster 2008, Komárek et al. 2008) indicating potentially large cyanobacterial biodiversity of the island (Vincent et Quesada 2012). Chroococcus sp., Leptolyngbya fritschiana, $L$. vincentii, $L$. borchgrevinkii, Phormidium priestleyi and Microcoleus autumnalis (former name Phormidium autumnale) are the most reported cyanobacterial species. Green algal species, although reported for the James Ross Island in the studies focused on the effects of abiotic factors on autotrophic communities (e.g. Nedbalová et al. 2013), have not yet been studied systematically. Only 6 freshwater algal species are reported by Elster et al. (2013) from James Ross Island and 3 algal species are cultivated in CCALA collection in Třeboň: Zygnema sp., Klebsormidium sp. and Heterococcus sp.

Thanks to facilities of J. G. Mendel Station (Prošek et al. 2013), a long-term research on physical (e.g. Váczi et Barták 2011), chemical and ecological characteristics (Nedbalová et al. 2013) of lakes of the James Ross Island has been conducted since 2006. In these studies, mineral ions contents in lakes and long-term water temperature courses are reported. Moreover, initial part of geochemical mapping based on strontium isotope ratio was done for some lakes, such as Phormidium Lake (Míková 2012). Autotrophic organisms associated with wet habitats of the James Ross Island have been studied with the main focus on diatoms (e.g. Esposito et al. 2008, Van de Vijver et al. 2011, Kopalová et al. 2011a, 2011b, 2012, 2013) and cyanobacteria (e.g. Komárek 2007, Komárek et al. 2012). Some specific aspects of cyanobacteria occurrence in lake ecosystems, such as formation of mineral structures similar to stromatolites (Elster et al. 2009) has been in focus as well. Algae have been studied less frequently, only 5 genera (Klebsormidium, Prasiola, Ulothrix, Tribonema and Hazenia) are reported for James Ross Island (Veselá 2007, Prošek et al. 2013, Škaloud et al. 2013). In our study, we therefore focus on preliminary report of algae and cyanobacteria from lakes and seepages of the northern ice-free area of James Ross Island. For sampling, several sites have been selected in respect to different lake and pond types, their freezing/thawing cycles and geographical location on the island. 


\section{Material and Methods}

\section{Sampling sites description}

Locations of 6 sampling sites are indicated in Fig. 1 and basic geographic information are given in Table 1. Detailed description of sampling site is given for each of them.

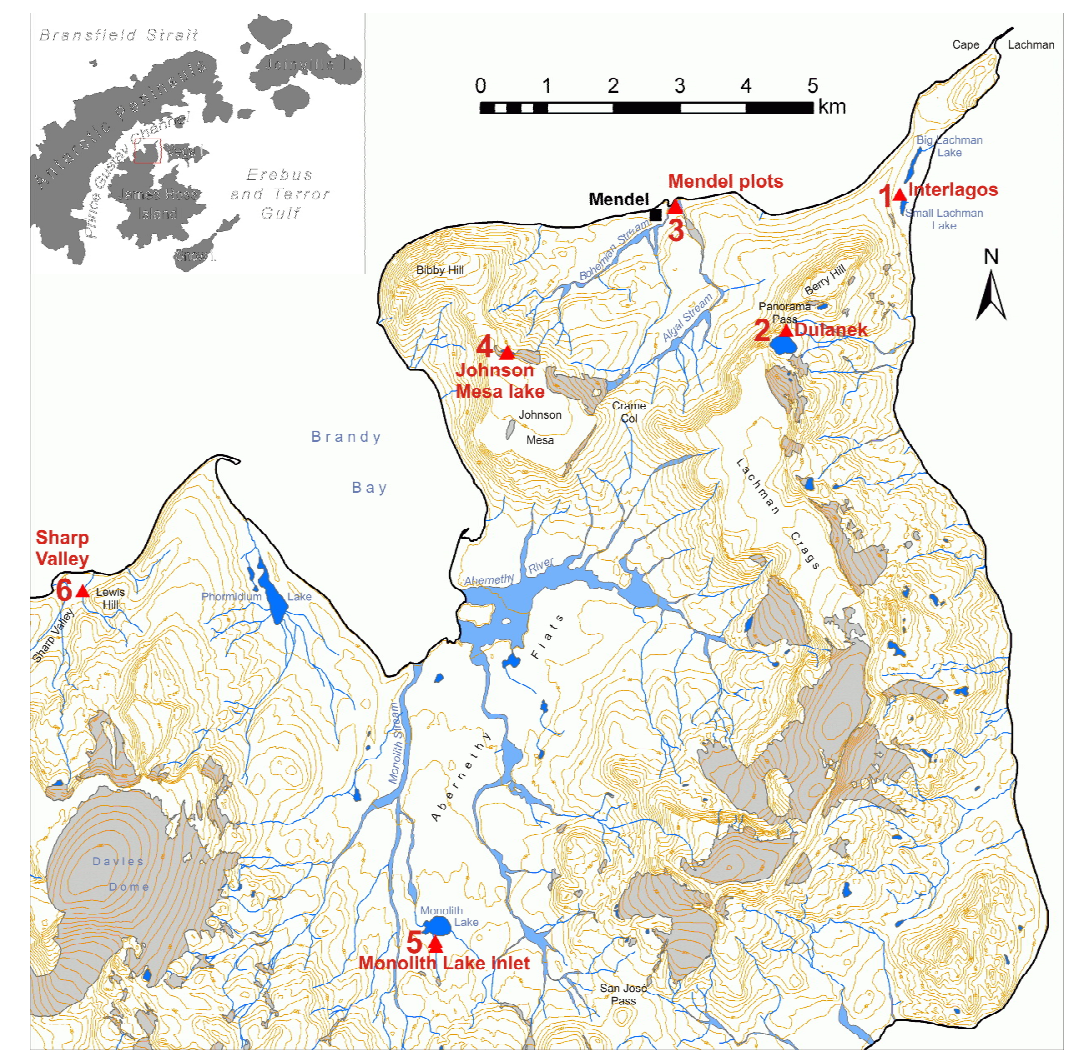

Fig. 1. Sampling sites located at the northern part of the James Ross Island - Ulu Peninsula: (1) Interlagos, (2) Dulanek Pond, (3) Mendel plots (Long-term experimental plots close to Mendel Station), (4) Johnson Mesa Lake, (5) Monolith Lake inlet, (6) Sharp Valley. Topographic base of Czech Geological Survey (2009).

\section{Interlagos ponds}

These are very shallow small ponds located in between Big and Small Lachman Lakes at the altitude of $\sim 10 \mathrm{~m}$ a.s.l. The Big and Small Lachman Lakes are typical shallow coastal lakes, which evolved after the retreat of the ice in the early Holocene time (Nedbalová et al. 2013) and are located in sedimentary rocks. In spite of the fact that Big and Small Lachman lakes are typical of high content of fine-grained clayey to silty particles originating from underlying Neogene glacigenic and glaciomarine sediments of the Mendel Formation (Nývlt et al. 2011) resulting in greyish-brown colour of turbulent water column, water in the Interlagos ponds is clear and rich in benthic microbial mats. For sampling of microbiological mats, the southern pond (Interlago 2) was used. Mean water temperature in the Interlago 2 for January is $7.2^{\circ} \mathrm{C}$ (Váczi et Barták 2011). Both the 
Interlagos ponds and Big and Small Lachman Lakes are affected by the sea proximity. Therefore, nutrient input from a sea-spray took place during windy days. Main source of water for the ponds and lakes are snowfields formed annually during austral winter thanks to local topography (see Fig. 2B in Nedbalová et al. 2013). If snow accumulation is not sufficient, lakes may dry out during summer season (Váczi et al. 2011).

\section{Dulanek Pond}

The Dulanek Pond is a typical small-area pool formed in a shallow depression on the surface of a left lateral glacier moraine made of large stones of hyaloclastite breccias with present ice core (e.g. Davies et al. 2013). Main source of water are snowfields formed annually in a neighbourhood of the pond during austral winter. The pond is located close to Panorama Pass at the altitude of $\sim 220 \mathrm{~m}$ a.s.l. about $2 \mathrm{~km}$ from coast. Typical pond area is of $\sim 25 \mathrm{~m}^{2}$. Maximum depth reaches $0.8 \mathrm{~m}$. Average annual and summer season temperature (December-February) is -4.6 and $2.1^{\circ} \mathrm{C}$, respectively (Váczi et al. 2011).

\section{Mendel plots (Long-term experimental plots close to Mendel Station)}

The plot is located in coastal area on the upper inactive part of Algal Stream delta only $80 \mathrm{~m}$ from the Mendel Station. The area is therefore supplied by water mainly from neighbouring snowfield that may remain for whole summer season. Occasionally, the snowfield may melt out in extremely hot and windy summer, which results in drying-out of the seepage and consequent full inhibition of photosynthetic activity of the autotrophs forming the community for several weeks (Barták, unpublished data from February 2009). The seepage is rich in moss and lichen flora. Therefore, a long-term research plot was established here in 2007 to study the probable effects of atmospheric warming on vegetation of Antarctic coastal oases using an open top chambers approach (Barták et al. 2009). An automatic weather station has recorded microclimate data here since 2007. The plot is characterized by annual mean air temperature $-4.6^{\circ} \mathrm{C}$ (Láska et al. 2011). In austral summers (November to February) mean temperature above the surface of moss cushion forming patchy vegetation cover of the long-term research plot is $4.1^{\circ} \mathrm{C}$ (recalculated from Láska et al. 2011).

\section{Johnson Mesa Lake}

The lake was formed after the glacier retreat from the cirque area on the northern slope of the Johnson Mesa at the altitude of $255 \mathrm{~m}$ a.s.l. (it is named Bibby Lake in Nedbalová et al. 2013). Recently, the lake is delimited by perpendicular rock wall from S-SW and dammed by a frontal moraine in the NE. The area of the lake is estimated to 7 $439 \mathrm{~m}^{2}$ (Nedbalová et al. 2013). Typically, the lake remains partly frozen during austral summer seasons. The recent main water source is the snow accumulation located on the NE slopes of Johnson Mesa formed thanks to prevailing SW winds during austral winters.

\section{Monolith Lake}

The lake is located in an inland area of the Ulu Peninsula, northern James Ross Island in the altitude of $67 \mathrm{~m}$ a.s.1., $\sim 6 \mathrm{~km}$ from the Brandy Bay seashore (see Fig. 1). It is a typical representative of stable lakes formed in old moraines, in this case after the mid-Holocene retreat of Whisky Glacier (Hjort et al. 1997, Nedbalová et al. 2013). It represents the second largest lake $\left(\sim 93000 \mathrm{~m}^{2}\right)$ in the ice-free area of northern Ulu Peninsula. The 
lake and two main inlets are rich in freshwater autotrophs. The surrounding of the two inlets is covered by well-developed patterned moss and lichen communities as well as microbial mats.

\section{Sharp Valley}

The samples were collected from one of the seepages formed along the sides of a stream close to Lewis Hill at the altitude of $10 \mathrm{~m}$ a.s.l. The site of collection was located $\sim 200$ $\mathrm{m}$ from the coast. Stony substrate forming valley floor originated from sedimentary rocks of the Bibby Point and Lewis Hill Members of the Whisky Bay Formation (Crame et al. 2006) rich in weathered dark green chloritic rocks originating from the rafts of the Nordenskjöld Formation. Therefore, the studied mineral formed a greenish inorganic layer, on which soil crust and seepages vegetation was formed.

\begin{tabular}{|c|c|c|c|c|c|}
\hline $\begin{array}{l}\text { Locality } \\
\text { No. }\end{array}$ & Sampling site & $\begin{array}{l}\text { Geographic } \\
\text { coordinates }\end{array}$ & Habitat & $\begin{array}{c}\text { Date of } \\
\text { collection }\end{array}$ & $\begin{array}{c}\mathrm{pH}, \text { water } \\
\text { temperature }\end{array}$ \\
\hline 1. & $\begin{array}{l}\text { Interlagos ponds } \\
\text { (Interlago 2) }\end{array}$ & $\begin{array}{l}63^{\circ} 47^{\prime} 56^{\prime \prime} \mathrm{S} \\
57^{\circ} 48^{\prime} 38^{\prime \prime} \mathrm{W}\end{array}$ & $\begin{array}{l}\text { Small-area } \\
\text { ponds in } \\
\text { sediments } \\
(10 \mathrm{~m} \text { a.s.l. })\end{array}$ & 6.2 .2013 & $\begin{array}{l}\mathrm{pH}=9.4 \\
\mathrm{t}=7.5^{\circ} \mathrm{C}\end{array}$ \\
\hline 2. & Dulanek Pond & & $\begin{array}{l}\text { Small-area pond } \\
\text { rich in mats } \\
(220 \text { m a.s.l.) }\end{array}$ & 2011 & \\
\hline \multirow[t]{3}{*}{3.} & \multirow[t]{3}{*}{$\begin{array}{l}\text { Mendel plots (Long- } \\
\text { term experimental } \\
\text { plots close to Mendel } \\
\text { Station - seepage) }\end{array}$} & $\begin{array}{l}63^{\circ} 48^{\prime} 01^{\prime \prime} \mathrm{S} \\
57^{\circ} 52^{\prime} 46^{\prime \prime} \mathrm{W} \\
\text { Site A }\end{array}$ & $\begin{array}{l}\text { Coastal } \\
\text { vegetation oasis } \\
\text { with moss and } \\
\text { lichen cover } \\
(5 \mathrm{~m} \text { a.s.l. })\end{array}$ & 14.2 .2013 & $\begin{array}{l}\mathrm{pH}=8.2 \\
\mathrm{t}=3.5^{\circ} \mathrm{C}\end{array}$ \\
\hline & & $\begin{array}{l}63^{\circ} 48^{\prime} 01^{\prime \prime} \mathrm{S} \\
57^{\circ} 52^{\prime} 45^{\prime \prime} \mathrm{W} \\
\text { Site B }\end{array}$ & $\begin{array}{l}\text { Vegetation } \\
\text { oasis with } \\
\text { formed moss } \\
\text { and lichen cover }\end{array}$ & 14.2.2013 & $\begin{array}{l}\mathrm{pH}=8.2 \\
\mathrm{t}=3.5^{\circ} \mathrm{C}\end{array}$ \\
\hline & & $\begin{array}{l}63^{\circ} 48^{\prime} 00^{\prime \prime} \mathrm{S} \\
57^{\circ} 52^{\prime} 45^{\prime \prime} \mathrm{W} \\
\text { Site C }\end{array}$ & $\begin{array}{l}\text { Vegetation } \\
\text { oasis with } \\
\text { formed moss } \\
\text { and lichen cover }\end{array}$ & 14.2 .2013 & $\begin{array}{l}\mathrm{pH}=8.2 \\
\mathrm{t}=3.5^{\circ} \mathrm{C}\end{array}$ \\
\hline \multirow[t]{2}{*}{4.} & \multirow[t]{2}{*}{ Johnson Mesa Lake } & $\begin{array}{l}63^{\circ} 49^{\prime} 11^{\prime \prime} \mathrm{S} \\
57^{\circ} 55^{\prime} 54^{\prime \prime} \mathrm{W} \\
\text { Site A }\end{array}$ & $\begin{array}{l}\text { Moraine lake } \\
(250 \mathrm{~m} \text { a.s.l.) }\end{array}$ & 29.1 .2013 & $\begin{array}{l}\mathrm{pH}=9.8 \\
\mathrm{t}=4.0^{\circ} \mathrm{C}\end{array}$ \\
\hline & & $\begin{array}{l}63^{\circ} 49^{\prime} 10^{\prime \prime} \mathrm{S} \\
57^{\circ} 55^{\prime} 52^{\prime \prime} \mathrm{W} \\
\text { Site B }\end{array}$ & $\begin{array}{l}\text { Moraine lake } \\
(250 \mathrm{~m} \text { a.s.l.) }\end{array}$ & 29.1 .2013 & $\begin{array}{l}\mathrm{pH}=9.8 \\
\mathrm{t}=4.0^{\circ} \mathrm{C}\end{array}$ \\
\hline \multirow[t]{2}{*}{5.} & \multirow[t]{2}{*}{ Monolith Lake - inlet } & $\begin{array}{l}63^{\circ} 53^{\prime} 56^{\prime \prime} \mathrm{S} \\
57^{\circ} 57^{\prime} 21 \text { ' W } \\
\text { Site A }\end{array}$ & $\begin{array}{l}\text { Inland lake } \\
\text { (67 } \mathrm{m} \text { a.s.1.) }\end{array}$ & 3.2 .2013 & $\begin{array}{l}\mathrm{pH}=8.3 \\
\mathrm{t}=2.2^{\circ} \mathrm{C}\end{array}$ \\
\hline & & $\begin{array}{l}63^{\circ} 53^{\prime} 59^{\prime \prime} \mathrm{S} \\
57^{\circ} 57^{\prime} 21^{\prime \prime} \mathrm{W} \\
\text { Site B }\end{array}$ & $\begin{array}{l}\text { Inland lake } \\
\text { (67 } \mathrm{m} \text { a.s.1.) }\end{array}$ & 3.2 .2013 & $\begin{array}{l}\mathrm{pH}=8.3 \\
\mathrm{t}=2.2^{\circ} \mathrm{C}\end{array}$ \\
\hline 6. & $\begin{array}{l}\text { Sharp Valley } \\
\text { (seepage) }\end{array}$ & & $\begin{array}{l}\text { Soil crust close } \\
\text { to the Sharp } \\
\text { Valley stream } \\
(10 \mathrm{~m} \text { a.s.l. })\end{array}$ & 2011 & \\
\hline
\end{tabular}

Table 1. General characteristics of sampling sites at the James Ross Island, Antarctica. 


\section{Sampling}

The communities of freshwater algae and cyanobacteria were sampled on the James Ross Island $\left(64^{\circ} 10^{\prime} \mathrm{S}, 57^{\circ} 45^{\prime} \mathrm{W}\right)$ in $2012 / 2013$ austral summer season. The collections were done during the Czech Polar Expedition in the area of ice-free Ulu Peninsula. All samples were collected at air temperature of $1-3^{\circ} \mathrm{C}$. Thus, the mats of algae and cyanobacteria exhibited physiological activity. Mat samples were collected into polyethylene vials of $50 \mathrm{ml}$ volume with a sufficient amount of ambient water. After collecting, the samples were stored at the temperature of $4^{\circ} \mathrm{C}$ in a refrigerator. The transport of samples to laboratories in the Czech Republic was carried out using a cooling container at the temperature around $0^{\circ} \mathrm{C}$.

Cyanobacterial communities of lakes in this area constitute a transitional zone between Maritime and Continental Antarctica (Komárek et Elster 2008). In this research, two samples from an inlet of old stable Monolith Lake were observed (see

\section{Optical Microscopy}

After transfer to Brno (Czech Republic), mat samples were analysed by an optical microscopy (Olympus BX50, Japan) and digital photograph of the species forming the mat were taken (Sony SLTA35 (HD AVCHD). Throughout all samples, more than 1000 photographs were

\section{Results and Discussion}

Total number of 41 algal and cyanobacterial taxa were found in ten samples from the material collected at 6 investigated sampling sites (see Fig. 1, Table 1). Biodiversity differed between sampling sites, however a large variation in species composition was found even within a single samples. It has been documented for the seepages close to the Mendel Station (Mendel plots, sampling site No. 3), where
Fig. 1). Furthermore, two samples from the Johnson Mesa Lake floor are also involved here. Due to low water level, the lake was divided into two parts in this season. The sample A (see Table 1) was collected from an overflow among these parts. The sample B was collected from layers of a mat near a bank. However, the main part of lake surface remained under the ice even during the high summer season. Algae and cyanobacteria from the Interlago 2 (one of the two ponds forming the Interlagos, for details see Váczi et Barták 2011) on the Cape Lachman were also collected. This site has been intensively studied since 2006. Samples of microbiological mats were collected from Dulanek Pond, a small-area pond rich in algae and cyanobacteria. Limnological characteristics of selected lakes were described in detail by Nedbalová et al. (2013). Other samples were collected in the seepages - three samples in Mendel plots and one in Sharp Valley close to a stream.

taken and analysed, so that individual matforming species could be distinguished. Morphologic approach was used to determine particular algal and cyanobacterial species. Relative frequencies of species were calculated for each sample.

three samples were collected (A, B, and C). In two of them, different dominant taxa were found: alga Zygnema sp. (see Fig. 2D) and cyanobacterium Nostoc sp. (see Fig. 3F). In the third one, an unidentified species was dominant. This might be attributed to a high biodiversity of green algal and cyanobacterial species of sampling site No. 3 (seepages). 


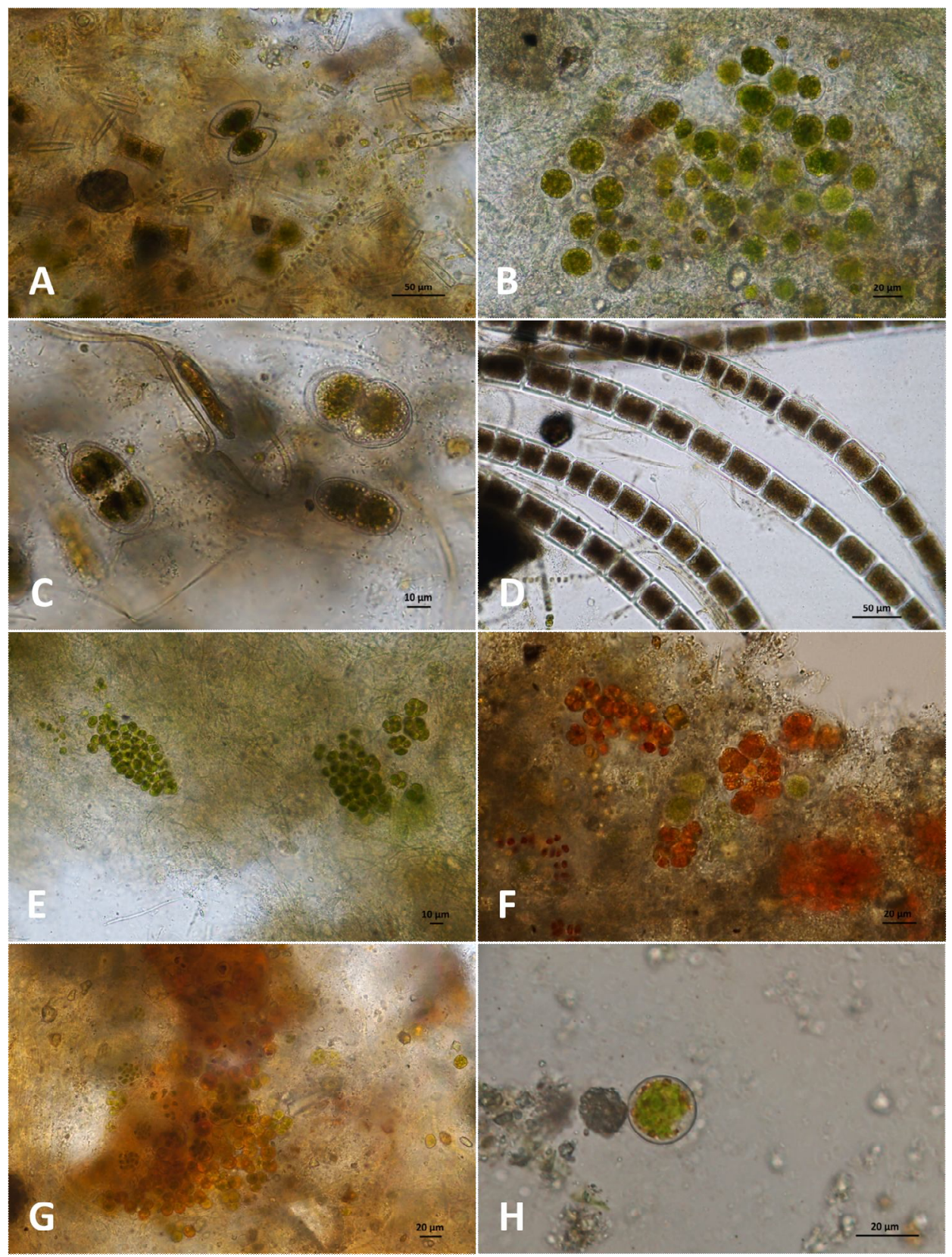

Fig. 2. Algae of James Ross Island - Ulu Peninsula. A - Staurastrum punctulatum, B - Chlorococcales (type 1), C - Actinotaenium curtum, D - Zygnema sp., E - Chlorococcales (type 2), $\mathrm{F}$ - Chlorococcales (type 3), $\mathrm{G}$ - unidentified algae, $\mathrm{H}$ - Chlorobotrys regularis. Photos: A-G by K. Skácelová, H by K. Trnková. 


\section{K. SKÁCELOVÁ et al.}

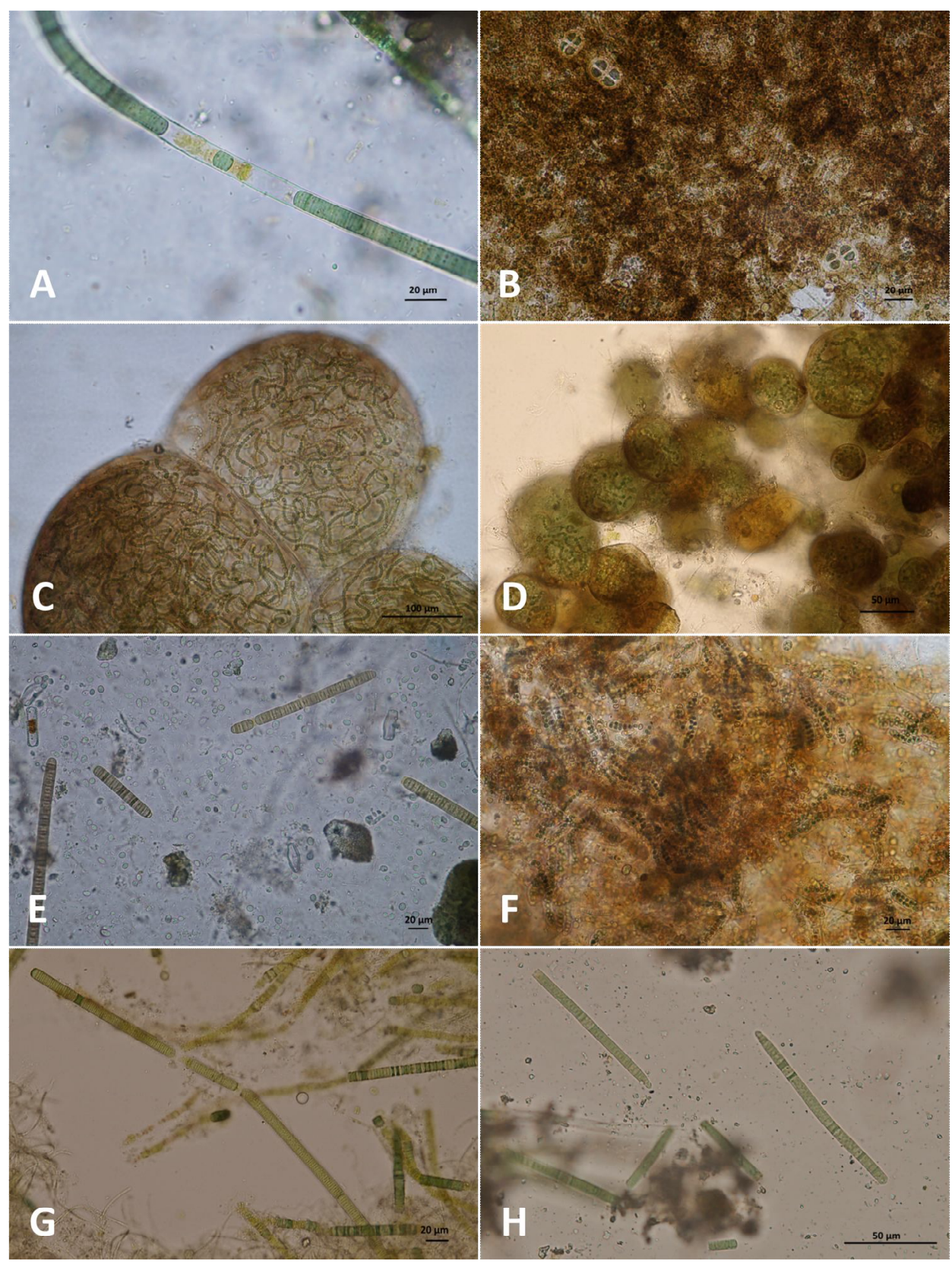

Fig. 3. Cyanobacteria of James Ross Island - Ulu Peninsula. A - Lyngbya sp., B - Chroococcus sp., C - Nostoc sp., D - Nostoc sp., E - Oscillatoria cf. subproboscidea, F - Nostoc sp., G - Blennothrix sp., H - Microcoleus autumnalis. Photos: A-G by K. Skácelová, H by K. Trnková. 
The effect of microrelief and spatial patchiness in water availability might be considered possible cause of such difference between single samples from sampling site No. 3. Another seepage (Sharp Valley, sampling site No. 6) was dominated by Microcoleus autumnalis (see Fig. $3 \mathrm{H}$ ). Total number of identified autotrophic microorganisms was 28 , however some of them has not yet been determined. The number of taxa found in sampling sites No. 3 and 6 supports the idea that seepages represent an important biotope in Antarctic ecosystems. Filamentous cyanobacteria are considered first colonizers of Antarctic seepages (Komárek et Komárek 2010), in which rich communities of algae and cyanobacteria form mats covering soil and/or stony surfaces. It is believed that community structure of algal species forming planktonic communities is dependent on seasonality (Izaguirre et al. 2001). In cyanobacterial mats, zonation is another factor affecting community structure. At the James Ross Island, such dependence was documented for e.g. Green Lake (Strunecký et al. 2011, Škaloud et al. 2013). Therefore, our further study will be focused on species biodiversity of mats from the seepages located close to the localities No. 1, 3 and 6, as dependent on the distance from main water source. The study will focus not only on taxonomy of the mat-forming species, but also on their physiological properties, temperature and irradiation optima during controlled growth in photobioreactors in particular (see e.g. Balarinová et al. 2013).

Similarly to seepages, samples from lakes exhibited different dominating taxa. While Nostoc sp. (see Fig. 3C, D) and Nitzschia sp. were most abundant in small -area ponds (sampling sites No. 1 and 2), the two genera were missing in the John- son Mesa Lake and Monolith Lake inlet, i.e. sampling sites No. 4 and 5. Leptolyngbya erebi was another dominant genus in small-area ponds (sites No. 1 and 2). In large-area lakes, no single dominant species was apparent. Further and more detailed sampling and consequent analyses of communities forming mats in large-area lakes are required in future studies, so that a presence or absence of the species typical for small-area pond such as e.g. Nostoc sp., Nitzschia sp., and Leptolyngbya sp. in large-area lakes of the James Ross Island could be evidenced. Generally, differences between small- and large-area ponds/lakes could be expected because of different water temperature courses during austral summer season (Váczi et Barták 2011). However, Nostoc sp. and Leptolyngbya sp. are reported to be frequent species at the James Ross Island (Komárek et Komárek 2010).

While colonies of Klebsormidium sp. followed by Gloeocapsopsis-like cyanobacterium dominated in the site $\mathrm{B}$ from the Johnson Mesa Lake, unidentified green alga (see Chlorococcales type 1 in Fig. 2B) was dominating in the site A. Sample rather than site-related community composition was found for autotrophs from the Monolith Lake (sampling site No. 5, see Fig. 1). While Zygnema sp. and Gomphonema sp. were most dominant in the site A, Microcoleus sp., Nostoc sp., and Leptolyngbya vincentii were the most frequent species/genera in the site B. However, when pooled, data showed relatively high number of 16 taxa found at the sampling site No. 5 (Monolith Lake). Therefore, the lake can be ranked as partially frozen inland lake with rich autotrophic flora in littoral zone (see e.g. Komárek 2007, Taton et al. 2011). 


\begin{tabular}{|c|c|c|c|c|c|c|c|c|c|c|}
\hline & \multirow[t]{2}{*}{ Interlago 2} & \multirow[t]{2}{*}{ Dulanek } & \multicolumn{3}{|c|}{ Mendel plots } & \multicolumn{2}{|c|}{\begin{tabular}{|c|} 
Johnson \\
Mesa Lake \\
\end{tabular}} & \multicolumn{2}{|c|}{$\begin{array}{c}\text { Monolith } \\
\text { Lake - inlet } \\
\end{array}$} & \multirow[t]{2}{*}{$\begin{array}{l}\text { Sharp } \\
\text { Valley }\end{array}$} \\
\hline & & & site $\mathrm{A}$ & site B & site $\mathrm{C}$ & site A & site B & site A & site B & \\
\hline \multicolumn{11}{|l|}{ CYANOBACTERIA } \\
\hline Blennothrix sp. & & +++ & & & & & & & & + \\
\hline Calothrix sp. & + & + & & & & & & & ++ & \\
\hline Cyanothece ohtani Komárek & & + & & + & & & & & & \\
\hline Gloeocapsa sp. & & + & & & & & & & & \\
\hline Hassalia sp. & & & & & & & & & + & + \\
\hline Chroococcus sp. & & & & & + & & & & & + \\
\hline $\begin{array}{l}\text { Leptolyngbya } \text { cf. } \\
\text { borchgrevinkii Komárek } 2007\end{array}$ & & & + & & & & & & & \\
\hline $\begin{array}{l}\text { Leptolyngbya erebi } \text { (West \& } \\
\text { G.S.West) Anagnostidis \& } \\
\text { Komárek } 1988\end{array}$ & +++ & ++ & +++ & + & ++ & & + & & & \\
\hline \begin{tabular}{|l|} 
Leptolyngbya fritschiana \\
Komárek 2007 \\
\end{tabular} & & & & +++ & & & & & & \\
\hline $\begin{array}{l}\text { Leptolyngbya vincentii } \\
\text { Komárek } 2006\end{array}$ & & & & & & & & ++ & +++ & \\
\hline Lyngbya sp. & ++ & + & & & + & & ++ & & + & \\
\hline $\begin{array}{l}\text { Microcoleus autumnalis } \\
\text { (C.Agardh) Rabenhorst } 1847\end{array}$ & & + & & + & + & & & & & +++ \\
\hline Microcoleus sp. & ++ & & & & & & & & +++ & \\
\hline \begin{tabular}{|l|} 
Nodularia quadrata \\
F.E.Fritsch 1912 \\
\end{tabular} & + & + & & & & & & & & \\
\hline Nostoc sp. & +++ & +++ & ++ & + & +++ & & & & +++ & \\
\hline $\begin{array}{l}\text { Oscillatoria } \text { cf. fracta Carlson } \\
1913\end{array}$ & + & & & & & & & & & \\
\hline $\begin{array}{l}\text { Oscillatoria } \text { cf. } \\
\text { subproboscidea } \text { West \& } \\
\text { G.S.West } 1911\end{array}$ & + & & ++ & & ++ & & & ++ & & \\
\hline Oscillatoria sp. & & & & ++ & & ++ & & & & + \\
\hline Phormidesmis sp. & ++ & & & & & & & & & \\
\hline $\begin{array}{l}\text { Wilmottia murrayi (West \& } \\
\text { G.S.West) Strunecký, Elster } \\
\text { \& Komárek } 2011 \\
\end{array}$ & & & ++ & & & & & & & \\
\hline Chroococcales (type 1) & + & & & & & & & + & & \\
\hline \multicolumn{11}{|l|}{ CHLOROPHYTA } \\
\hline $\begin{array}{l}\text { Actinotaenium curtum } \\
\text { (Brébisson ex Ralfs) Teiling } \\
1978\end{array}$ & & & & ++ & & & & & & \\
\hline Cosmarium $\mathrm{sp}$. & & + & & + & + & + & & + & + & \\
\hline Klebsormidium sp. & & & + & + & + & & +++ & + & & \\
\hline $\begin{array}{l}\text { Staurastrum punctulatum } \\
\text { Brébisson, } 1848\end{array}$ & & & & & & & & + & & \\
\hline Ulothrix sp. & & & & ++ & & & & & & \\
\hline Zygnema sp. & + & & & +++ & + & & & +++ & + & \\
\hline Chlorococcales (type 1) & ++ & & & & & & & & & \\
\hline Chlorococcales (type 2) & ++ & & ++ & & & & ++ & & & \\
\hline Chlorococcales (type 3) & & & & & & +++ & & & & \\
\hline Chlorococcales (type 4) & & & & & & & ++ & ++ & & \\
\hline \multicolumn{11}{|l|}{ BACILLARIOPHYCEAE } \\
\hline Amphora sp. & ++ & & & & & & & & & \\
\hline Eucocconeis sp. & & & + & & & & & & & \\
\hline Fragillaria sp. & + & & & & & & & & & \\
\hline Gomphonema sp. & + & & & & & & & +++ & + & \\
\hline Hantzschia sp. & & + & ++ & & & & & & + & \\
\hline Luticola sp. & & & & & & & ++ & & & \\
\hline Navicula sp. & & + & + & & & & & & & \\
\hline Nitzschia sp. & +++ & ++ & & & & & & & & \\
\hline
\end{tabular}




\begin{tabular}{|l|l|l|l|l|l|l|l|l|l|l|}
\hline Pinnularia sp. & & & & & \\
\hline
\end{tabular}

Table 2. Occurrence of algal and cyanobacterial taxa at single sampling sites on James Ross Island - Ulu Peninsula. +++ means frequent taxa, ++ medium occurring taxa, + rare taxa.

In conclusion, diversity of algae and cyanobacteria was site-specific, however, may be ranked as generally high. When compared to the number of genera/species presented by Veselá (2007), who studied biodiversity in two coastal streams of the James Ross Island (see Bohemian and Algal Streams in Fig. 1), our data supports the conclusion of high biodiversity in freshwater ecosystems, lakes in particular,

\section{Concluding remarks}

Antarctic lakes and water ponds differ in a biodiversity of their benthic mats. Some could be monospecific, formed typically by a single cyanobacterium, the others could be formed by several dominant species (Singh et Elster 2007). According to the scheme, the lakes and seepages investigated in our study might be classified as species-rich. Algal and cyanobacterial communities forming a mat of the Dulanek Pond consist of at least 15 species. Therefore, it can be ranked as a complex and species-rich microbial community. Similar classification could be done for Interlago 2 because at least 18 autotrophic organisms have been distinguished, although not completely determined.

In conclusion, the biodiversity of algal and cyanobacterial species in majority of the studied sites might be higher than reported in this study, because some species at the James Ross Island. Veselá (2007) reported 15 species of cyanobacteria and four genera of algae. Our study resulted in total of 41 freshwater autotrophs. Some taxa are reported for the first time for James Ross Island: Cosmarium sp., Actinotaenium curtum (see Fig. 2C), Staurastrum punctulatum (see Fig. 2A) and Chlorobotrys regularis (see Fig. $2 \mathrm{H}$ ).

have not yet been determined (see Fig. 2B, E, F, G). Furthermore, future sampling of the sites at the James Ross Island will undoubtedly bring new species because there are numerous wet ecosystems varying in ecological conditions. This is promising for future studies on biodiversity of algae and cyanobacteria in ice-free part of the James Ross Island. Recently, microorganisms from extreme environments, including Polar Regions (e.g. FernándezValiente et al. 2007), represent a great potential for biotechnology since they may be used as a source of secondary compounds that exhibit biological activity. Therefore, the knowledge of biodiversity of freshwater algae and cyanobacteria of the James Ross Island may help bioprospection of the island and future algal biotechnologies. 
K. SKÁCELOVÁ et al.

\section{References}

BALARINOVÁ, K., VÁczi, P., BARTÁK, M., HAZdrovÁ, J. and ForbelskÁ, M. (2013): Temperaturedependent growth rate and photosynthetic performance of Antarctic symbiotic alga Trebouxia sp. cultivated in a bioreactor. Czech Polar Reports, 3: 19-27.

Barták, M., Láska, K., Prošek, P., Hájek, J. and VÁczi, P. (2009): Long-term study on vegetation responses to manipulated warming using open top chambers installed in three contrasting Antarctic habitats. In: M. Barták, J. Hájek, P. Váczi (eds.): Structure and Function of Antarctic Terrestrial Ecosystems. Book of Abstracts and Contributed Papers. Conference, Brno, October $22^{\text {th }}-23^{\text {th }}, 2009$. Masaryk University, Brno, Czech Republic. Masaryk University, Brno, pp. 48-51.

CAMERON, R. E. (1970): Microorganisms and ecological investigations of recent cinder comes, Deception Island, Antarctica. A preliminary report. Ecology, 21: 802-807.

Crame, J. A., Pirrie, D. and Riding, J. B. (2006): Mid-Cretaceous stratigraphy of the James Ross Basin, Antarctica. In: J. E. Francis, D. Pirrie, J. A. Crame (eds.): Cretaceous-Tertiary highlatitude palaeoenvironments: James Ross Basin, Antarctica. Geological Society, London, Special Publication, 258: 7-19.

Davies, B. J., Glasser, N. F., Carrivick, J. L., Hambrey, M. J., Smellie, J. L. and NÝvlt, D. (2013): Landscape evolution and ice-sheet behaviour in a semi-arid polar environment: James Ross Island, NE Antarctic Peninsula. In: M. J. Hambrey, P. F. Barker, P. J. Barrett, V. Bowman, B. Davies, J. L. Smellie, M. Tranter (eds.): Antarctic Palaeoenvironments and EarthSurface Processes. Geological Society, London, Special Publication, 381: 352-395.

Elster, J., KomÁreK, J. and NedBalovÁ, L. (2013): Biodiverzita řas a sinic. In: P. Prošek (ed.): Antarktida. Academia Publishing House, Prague, Czech Republic. pp. 303-311.

Elster, J., NedbalovÁ, L., KomÁreK, J. and VodrÁžKA, R. (2009): Biogenic calcite structures in Green Lake, James Ross Island, Antarctica. In: M. Barták, J. Hájek, P. Váczi (eds.): Structure and Function of Antarctic Terrestrial Ecosystems. Book of Abstracts and Contributed Papers. Conference, Brno, October $22^{\text {th }}-23^{\text {th }}$, 2009. Masaryk University, Brno, Czech Republic. Masaryk University, Brno, 2009, pp. 38-40.

Esposito, R. M. M., Spaulding, S. A., McKnight, D. M., Van De Vijver, B., Kopalova, K., Lubinski, D., HAll, B. and WhitTAKer, T. (2008): Inland diatoms from the McMurdo Dry Valleys and James Ross Island, Antarctica. Botany, 86: 1378-1392.

Fernández-Valiente, E., CAmacho, A., Rochera, C., Rico, E., Vincent, W. F. and Quesada, A. (2007): Community structure and physiological characterization of microbial mats in Byers Peninsula, Livingston Island (South Shetland Islands, Antarctica). FEMS Microbiology Ecology, 59: 377-385.

Hawes, I., Brazier, P. (1991): Freshwater stream ecosystems of James Ross Island, Antarctica. Antarctic Science, 3: 265-271.

HJoRT, C., IngÓLfSSON, Ó., MÖLler, P. and LiRIO, J. M. (1997): Holocene glacial history and sealevel changes on James Ross, Antarctic Peninsula. Journal of Quaternary Science, 12: 259-273.

Izaguirre, I., Mataloni, G., Allende, L. and Vinocur, A. (2001): Summer fluctuations of microbial planktonic communities in a eutrophic lake - Cierva Point, Antarctica. Journal of Plankton Research, 23: 1095-1109.

KomÁReK, J. (2007): Phenotype diversity of the cyanobacterial genus Leptolyngbya in the maritime Antarctic. Polish Polar Research, 28: 211-231.

KomÁReK, J., Elster, J. (2008): Ecological background of cyanobacterial assemblages of the northern part of James Ross Island, Antarctica. Polish Polar Research, 29: 17-32.

KOMÁREK, J., ElSTER, J. and KOMÁREK, O. (2008): Diversity of the cyanobacterial microflora of the northern part of James Ross Island, NW Weddell Sea, Antarctica. Polar Biology, 31: 853 -865 .

KomÁreK, O., KomÁrek J. (2010): Diversity and Ecology of Cyanobacterial Microflora of Antarctic Seepage Habitats: Comparison of King George Island, Shetland Islands, and James Ross Island, NW Weddell Sea, Antarctica. In: J. Sekbach, A. Oren (eds.): Microbial Mats: Modern and Ancient Microorganisms in Stratified Systems, 14: 515-539. 
KomÁreK, J., Nedbalová, L. and Hauer, T. (2012): Phylogenetic position and taxonomy of three heterocytous cyanobacteria dominating the littoral of deglaciated lakes, James Ross Island, Antarctica. Polar Biology, 35: 759-774.

KopalovÁ, K., Elster, J., NedbalovÁ, L. and VAn DE ViJVer, B. (2011a): Three new terrestrial diatom species from seepage areas on James Ross Island (Antarctic Peninsula Region). Diatom Research, 24: 113-122.

Kopalová, K., Nedbalová, L., de HaAn, M. and Van de Vijver, B.V. (2011b): Description of five new species of the diatom genus Luticola (Bacillariophyta, Diadesmidaceae) found in lakes of James Ross Island (Maritime Antarctic Region). Phytotaxa, 27: 44-60.

Kopalová, K., Nedbalová, L., NÝvlt, D., Elster, J. and Van De ViJver, B. (2013): Diversity, ecology and biogeography of the freshwater diatom communities from Ulu Peninsula (James Ross Island, NE Antarctic Peninsula). Polar Biology, 36: 933-948.

Kopalová, K., Veselá, J., Elster, J., NedbalovÁ, L., KomÁrek, J. and Van de Vijver, B. (2012): Benthic diatoms (Bacillariophyta) from seepages and streams on James Ross Island (NW Weddell Sea, Antarctica). Plant Ecology and Evolution, 145: 190-208.

Láska, K., Barták, M., Hájek, J., Prošek, P. and Bohuslavová, O. (2011): Climatic and ecological characteristics of deglaciated area of James Ross Island, Antarctica, with a special respect to vegetation cover. Czech Polar Reports, 1: 49-62.

MíkovÁ, J. (2012): Strontium isotopic signatures of the Torrent Valley streams and Phormidium Lake on James Ross Island, Antarctica. Book of Abstracts, Polar Ecology Conference, České Budějovice, Czech Republic, pp. 77-78.

NedbalovÁ, L., NÝvlt, D., KopÁČEK, J., Šobr, M. and Elster, J. (2013): Freshwater lakes of Ulu Peninsula, James Ross Island, northeast Antarctic Peninsula: origin, geomorphology and physical and chemical limnology. Antarctic Science, 25: 358-372.

NÝVlt, D., KoŠLer, J., MLČoch, B., MiXA, P., LisÁ, L., BubíK, M. and HendRiKs, B.W.H. (2011): The Mendel Formation: Evidence for Late Miocene climatic cyclicity at the northern tip of the Antarctic Peninsula. Palaeogeography, Palaeoclimatology, Palaeoecology, 299: 363-384.

Prošek, P., BARTÁk, M., LÁska, K., SuCháneK, A., HÁJeK, J. and KaPler, P. (2013): Facilities of J. G. Mendel Antarctic station: Technical and technological solutions with a special respect to energy sources. Czech Polar Reports, 3: 38-57.

Singh, S. M., Elster, J. (2007): Cyanobacteria in Antarctic Lake Environments. A mini-review. In: J. Seckbach (ed.): Algae and Cyanobacteria in Extreme Environments. Springer, pp. 305 -320 .

Strunecký, O., Elster, J. and KomÁRek, J. (2011): Taxonomic revision of the freshwater cyanobacterium ,Phormidium “ murrayi = Wilmottia murrayi. Fottea, 11: 57-71.

ŠKaloud, P., NedbalovÁ, L., Elster, J. and KomáReK, J. (2013): A curious occurrence of Hazenia broadyi spec. nova in Antarctica and the review of the genus Hazenia (Ulotrichales, Chlorophyceae). Polar Biology, 36: 1281-1291.

Taton, A., Wilmotte, A., Šmarda, J., Elster, J. and Komárek, J. (2011): Plectolyngbya hodgsonii: a novel filamentous cyanobacterium from Antarctic lakes. Polar Biology, 34: 181 $-191$.

Temniskova-Topalova, D., KirJakov, I. (2002): Distribution of Freshwater Algae on Livingston Island, South Shetlands. I. Green Algae (Chlorophyta). In: V. Golemansky, N. Chipev (eds.): Bulgarian Antarctic Research, 3: Life Sciences. Pensoft Publishers, Sofia, Bulgaria, pp. 51-68.

VÁCZI, P., BARTÁK, M. (2011): Summer season variability of dissolved oxygen concentration in Antarctic lakes rich in cyanobacterial mats. Czech Polar Reports, 1: 42-48.

VÁczi, P., BARTÁK, M., NEdBAlovÁ, L., Elster, J. (2011): Comparative analysis of temperature courses in Antarctic lakes of different morphology: Study from James Ross Island, Antarctica. Czech Polar Reports, 1: 78-87.

VAn DE ViJver, B., Zidarova, R. and DE HAan, M. (2011): Four new Luticola taxa (Bacillariophyta) from the South Shetland Islands and James Ross Island (Maritime Antarctic Region). Nova Hedwigia, 92: 137-158. 
VeSELÁ, J. (2007): Diverzita a ekologie řas a sinic Vodárenského a Řasového potoka na ostrově Jamese Rosse, Antarktida. Bakalářská práce. Jihočeská univerzita v Českých Budějovicích, s. 26. (Diversity and ecology of algae and cyanobacteria of waterwork and Algal streams at the James Ross Island, Antarctica - In Czech).

VINCENT, W. F., QuESADA, A. (2012): Cyanobacteria in High Latitude Lakes, Rivers and Seas. In: B. A. Witton (ed.): Ecology of Cyanobacteria II: Their Diversity in Space and Time. Springer, pp. 371-385.

ZidAROVA, R. P. (2008): Algae from Livingston Island (S Shetland Islands): a checklist. Phytopatologia Balcanica, 14: 19-35.

\section{Other sources}

Czech Geological Survey (2009). James Ross Island - Northern Part. Topographic map $1: 25000$. ISBN 978-80-7075-734-5. 